\title{
EPIC MODEL: EFEKTIVITAS IKLAN DESTINASI WISATA KABUPATEN BANYUWANGI TERHADAP MINAT BERKUNJUNG ULANG WISATAWAN DOMESTIK
}

\author{
Ika Barokah Suryaningsih \\ barokah.feb@unej.ac.id \\ Kristian Suhartadi Widi Nugraha \\ kristian.feb@unej.ac.id
}

Fakultas Ekonomi dan Bisnis, Universitas Jember, Jawa Timur

\begin{abstract}
Visiting a tourist destination is influenced by advertising through the internet, for example, facebook, Instagram, traveler blogger, kaskus, and so on. All tourism promotion processes are carried out online, so that tourists can search everything about tourist destinations that will be addressed wherever and whenever comfortably. This can foster interest in revisiting tourists for tourist destinations in Banyuwangi Regency. This study aims to determine the effectiveness of online advertising in all tourist destinations in Banyuwangi Regency, both nature-based tourism and Banyuwangi art-based tourism. Methods of data collection in this study using survey of all tourists who provide testimonials or expressions of tourism in Banyuwangi through online media. It is tourists who intend to visit tourist destinations in Banyuwangi Regency. Primary data is obtained from the results of questionnaires distributed to respondents distributed online through google.doc. The data analysis technique uses the EPIC method model which consists of four dimensions namely empathy, persuasion, impact and communication. Processing data to get the results of advertising effectiveness is used simple tabulation analysis, mean score, and EPIC rate. Based on the results of EPIC rate analysis, the EPIC rate value is 3.66 which if included in the EPIC rating scale Model is included in the effective category. Thus the advertisement of tourist destinations in Banyuwangi Regency is done using online media effectively against the interest of revisiting domestic tourists.
\end{abstract}

Keywords: EPIC Model, Banyuwangi, tourism, destination.

\section{PENDAHULUAN}

\section{Latar Belakang}

Seiring semakin berkembangnya teknologi dan informasi, semakin banyak pula para pengguna yang menggunakan teknologi dan informsi untuk memudahkan pekerjaan. Internet merupakan salah satu dari teknologi informasi yang banyak digunakan saat ini. Pengguna dapat dengan mudah mengakses internet kapan saja 
dan dimana saja,misalnya dengan menggunakan handphone, laptop ataupun komputer tablet. Pada tahun 2018, pengguna internet di Indonesia sebanyak 123 juta jiwa dan berada pada posisi keenam dunia (www.emarketer.com). Pada tabel 1 berikut adalah kenaikan pengguna internet di Indonesia.

Tabel 1. Pengguna Internet di Indonesia (Juta Jiwa)

\begin{tabular}{ccccccc}
\hline Tahun & 2013 & 2014 & 2015 & 2016 & 2017 & 2018 \\
\hline Pengguna & 72.8 & 83.7 & 93.4 & 102.8 & 112.6 & 123 \\
\hline
\end{tabular}

Sumber : www.emarketer.com tahun 2018

Berdasarkan laporan dari Asosiasi Penyelenggara Jasa Internet Indonesia (APJII) bahwa dari pengakses internet tersebut sekitar $51.43 \%$ berjenis kelamin laki-laki dan $48.57 \%$ berjenis kelamin perempuan. Adapun berdasarkan usia, sebanyak $16,68 \%$ pengguna berusia 13-18 tahun dan 49,52 \% berusia 19-34 tahun, pengguna internet berusia 35-54 tahun mencapai 29,55\%. Pengguna internet berusia 54 tahun ke atas mencapai 4,24\%.. Berdasarkan sebaran wilayah, sebanyak 58.08\% pengguna internet ada Pulau Jawa, sekitar 19\% di Pulau Sumatera, 7.97\% pengguna di Pulau Kalimantan, 5.63\% pengguna internet dari pulau Bali dan Nusa Tenggara, $6.73 \%$ pengguna internet dari Pulau Sulawesi dan $2.49 \%$ pengguna internet dari Maluku dan Papua (https://ekonomi.kompas.com/read/2018/02/19/161115126).

Tingginya pengguna internet di Indonesia memunculkan berbagai ide bagi sebagian orang untuk menggunakannya sebagai media promosi dan media iklan berbagai produk(Bestriandita \& Widodo, 2017; Riyantoro \& Harmoni, 2013).Dengan munculnya internet dan media sosial ibarat pedang bermata dua bagi pemilik usaha, pada suatu sisi dapat dijadikan sebagai sarana promosi yang murah dan efektif namun disisi lain juga memperburuk kondisi jika terdapat suatu keluhan atau publisitas negative. Sehingga suatu usaha dituntut untuk hati - hati dalam memposisikan produknya.

Kemahiran menggunakan alat promosi seperti periklanan wajib bagi suatu usaha(Ayu, et al, 2017; Salim \& Bachri, 2014). Hal ini berdasarkan asumsi bahwa iklan dapat dikatakan efektif ketika mampu mengkomunikasikan pesan dan seringkali juga suatu iklan mampu masuk ke dalam benak wisatawan meski hal tersebut belum mampu menggerakkan mereka untuk melakukan pembelian yang menjadi tujuan utama usaha pemasaran(Ayu et al., 2017; Bestriandita \& Widodo, 2017; Wijaya \& Dharmayanti, 2014). Karena pengukuran iklan sulit dilakukan jika dihubungkan dengan penjualan maka pemasar tertarik untuk mengukur sejauh mana suatu iklan dapat dievaluasi oleh wisatawan. EPIC Model adalah model untuk mengukur efektivitas iklan yang dikembangkan oleh A.C Nielsen salah satu perusahaan peneliti pemasaran terkemuka di dunia yang mencakup empat dimensi kritis, yaitu: empati, persuasi, dampak, dan komunikasi (Empathy, Persuasion, Impact, andComunication). Dari keempat dimensi kritis tersebut akan didapatkanbatasan (range) yang akan menentukan posisi suatu iklan (Durianto, 2003:86). Metode ini memungkinkan untuk melihat pada penilaian masing-masing 
dari dimensi emphaty, persuasion, impact dan communication secara terpisah sehingga dapat memudahkan perusahaan untuk mengatasi kelemahan pada dimensi yang dinilai paling tidak efektif.

Sejumlah alasan mengapa banyak perusahan memasang iklan melalui media internet dikarenakan wisatawan mulai berpindah ke internet(Ayu et al., 2017; Bestriandita \& Widodo, 2017), maka media iklan harus mengikutinya, dengan asumsi bahwa pengiklanan dalam bentuk apapun harus dapat menjangkau target audiennya secara efektif dan efesien (Suyanto, 2003: 65). Kompas, dalam (Tjiptono dan Santoso, 2000: 5) merilis bahwapengguna internet di Indonesia, sebagian besar digunakan untuk keperluan bisnis sebesar $43 \%$, sedangkan keperluan untuk pribadi sebanyak $32 \%$.

Banyuwangi merupakan salah satu kabupaten di Provinsi Jawa Timur. Akhir-akhir ini, Banyuwangi menjadi rising star pariwisata di selatan Jawa dan di Indonesia. Dengan memanfaatkan potensi yang dimiliki baik potensi alam dan budaya, Banyuwangi mampu membangun industry pariwisatanya menjadi lebih sinergi dan berdaya saing. Pada tahun 2016, wisatawan domestic yang mengunjungi Banyuwangi sebanyak 551.513 wisatawan dan naik menjadi 606.664 wisatawan pada tahun 2017, demikian juga wisatawan mancanegara mengalami kenaikan dari tahun 2016 sebanyak 64.102 wisman yang berkunjung ke Banyuwangi menjadi 71.217 wisman pada tahun 2017 (BPS Kabupaten Banyuwangi, 2018:215). Dengan mengambil tema Majestic Banyuwangi dan tagline Jelajahi Banyuwangi, Anda Pasti Ingin Kembali, Pemerintah Kabupaten Banyuwangi membangun pariwisata di segala sektor baik bersifat pengembangan maupun benar-benar baru. Selain itu, banyuwangi menjadi leading di kawasan Tapal Kuda karena memiliki 6 hotel berbintang dan 76 hotel non bintang, serta pengembangan Bandara Blimbing Sari yang berhasil mencatatkan sekitar 93.391 penumpang yang datang ke Banyuwangi pada tahun 2017 (BPS Kabupaten Banyuwangi, 2018:205).

Berdasar uraian tersebut dapat diartikan bahwa perkembangan teknologi dan informasi serta perkembangan internet sendiri, memberikan dampak terhadap kegiatan pemasaran khusunya periklanan. Dari periklanan menggunakan media koran, radio atau televisi ke periklanan menggunakan menggunakan internet.Hal ini yang menjadikan penulis ingin mengetahui keefektifitasan iklan onlineyang digunakan olehkabupaten Banyuwangi dalam mempromosikan desninasi wisatanya. Penulis meneliti pengaruh tersebut dari metode EPIC (emphaty, persuasion, impact and Communication) yang ditemukan oleh lembaga riset AC. Nielsen.Berdasarkan latar belakang masalah tersebut diatas, peneliti mencoba mengidentifikasi permasalahan yaitu Apakah efekifitas iklan online destinasi wisata Banyuwangi berpengaruh secara simultan terhadap minat berkunjung ulang wisatawan domestik? 


\section{TINJAUAN PUSTAKA}

\section{EPIC Model}

Durianto (2003:86) menyatakan bahwa EPIC Model adalah salah satu alat ukur efektifitas iklan dengan pendekatan komunikasi yang dikembangkan oleh AC Nielsen - salah satu perusahaan peneliti pemasaran terkemuka di dunia - yang mencakup empat dimensi kritis, yaitu : empati, persuasi, dampak, dan komunikasi (Empathy, Persuation, Impact, and Communication). Berikut akan dipaparkan dimensi-dimensi dalam EPIC model :

1. Dimensi Empati

Empati (empathy) merupakan keadaan mental yang membuat seseorang mengidentifikasikan dirinya atau merasa dirinya pada keadaan perasaan atau pikiran yang sama dengan orang atau kelompok lain. Dimensi empati menginformasikan, apakah wisatawan menyukai suatu iklan dan menggambarkan bagaimana wisatawan melihat hubungan antara suatu iklan dengan pribadi mereka (Durianto, 2003:86). Empati adalah kemampuan memproyeksikan diri kepada diri orang lain dengan perkataan, kemampuan menghayati perasaan orang lain atau merasakan apa yang dirasakan orang lain (Effendy, 2003:13). Empati dalam periklanan adalah respon afektif yang berakar dari pengertian mengenai status atau kondisi emosi orang lain. Pemirsa seakan merasakan jika mereka adalah partisipasi dalam emosi dan sensasi orang lain (Hanna, 2001:333;Rahayu, 2012; Riyantoro \& Harmoni, 2013; Salim \& Bachri, 2014). Manusia bisa merasakan empat tipe respon afektif: emosi, perasaan khusus, suasana hati, dan evaluasi. Setiap tipe dari afeksi dapat melibatkan respon positif atau negatif. Emosi seperti takut dapat membangkitkan respon psikologikal seperti gembira, cinta, takut, marah, merasa bersalah; perasaan khusus dapat membangkitkan sedikit reaksi psikologikal seperti ramah, puas, menghargai, memuakkan, kesedihan; suasana hati dapat menciptakan tingkat rendah dari suatu perasaan yang intensif seperti santai, tenang, sedih, bosan, lesu; evaluasi seringkali medapatklan respon afektif yang paling rendah daripada tiga tipe afeksi seperti suka, baik, menyenangkan, tidak suka, tidak baik, tidak menyenangkan (Peter and Olson, 2000:193).

\section{Dimensi Persuasi}

Persuasi (persuasion) adalah perubahan kepercayaan, sikap, dan keinginan berperilaku yang disebabkan suatu komunikasi promosi(Ayu et al., 2017; Bestriandita \& Widodo, 2017; Rahayu, 2012). Proses persuasi yang akan dipakai ditentukan dengan tingkat keterlibatan wisatawan dalam pesan produk. Dimensi persuasi menginformasikan apa yang dapat diberikan suatu iklan untuk peningkatan atau penguatan karakter suatu merek, sehingga pemasang iklan memperoleh pemahaman tentang dampak iklan terhadap keinginan wisatawan untuk membeli serta memperoleh gambaran kemampuan suatu iklan dalam mengembangkan daya tarik suatu merek (Durianto, 2003,87).Persuasi (Persuasion) adalah perubahan kepercayaan, sikap, dan keinginan beperilaku yang disebabkan 
satu komunikasi promosi. Proses persuasi yang akan dipakai ditentukan dengan tingkat keterlibatan wisatawan dalam pesan produk (Peter and Olson, 2000:195).

\section{Dimensi Dampak}

Impact berarti iklan dinilai apakah mampu menangkap perhatian wisatawan dan meningkatkan pengenalan merek atau tidak. Dampak (impact) yang diinginkan dari hasil iklan adalah jumlah pengetahuan produk (product knowledge) yang dicapai wisatawan melalui tingkat keterlibatan (involvement) wisatawan dengan produk dan atau proses pemilihan. Wisatawan memiliki tingkat pengetahuan produk (levels of product knowledge) yang berbeda-beda, yang dapat digunakan untuk menerjemahkan informasi baru dan membuat pilihan pembelian. Wisatawan dapat memiliki empat tingkat pengetahuan produk, yaitu: kelas produk, bentuk produk, merek, dan model. Keterlibatan (involvement) mengacu pada persepsi wisatawan tentang pentingnya ataurelevansi personal suatu objek, kejadian, atau aktifitas. Wisatawan yang melihat bahwa suatu produk memiliki konsekuensi yang relevan secara pribadi, maka wisatawan dikatakan terlibat dengan produk tersebut dan memiliki hubungan dengan produk tersebut(Ayu et al., 2017). Konsekuensi dengan suatu produk atau suatu merek memiliki aspek kognitif maupun pengaruh. Secara kognitif, yang termasuk dalam keterlibatan adalah pengaruh, seperti evaluasi produk. Jika keterlibatan suatu produk tinggi, maka orang akan mengalami tanggapan pengaruh yang lebih kuat, seperti emosi dan perasaan yang kuat. Keterlibatan dapat berkisar dari tingkat yang rendah (tidak ada elevansinya) ke tingkat yang moderat (ada relevansi yang dirasakan) hingga ke tingkat yang tinggi (relevansinya sangat dirasakan). Keterlibatan adalah status motivasi yang menggerakkan serta mengarahkan proses kognitif dan perilaku wisatawan pada saat mereka membuat keputusan (Durianto, 2003:89).

\section{Dimensi Komunikasi}

Dimensi komunikasi memberikan informasi tentang kemampuan wisatawan dalam mengingat pesan utama yang disampaikan, pemahaman wisatawan, serta kekuatan kesan yang ditinggalkan pesan tersebut(Hastuti, 2013). Perspektif pemrosesan kognitif adalah inti untuk mengembangkan strategi promosi yang berhasil yang merupakan permasalahan komunikasi. Proses dimulai ketika sumber komunikasi promosi menentukan informasi apa yang harus dikomunikasikan, kemudian mengenkoding pesan tersebut dalam simbol-simbol yang paling tepat (menggunakan kata, gambar, atau tindakan). Kemudian, pesan ditransmisikan ke sebuah penerima melalui berbagai media, seperti pertunjukan televisi, penawaran via pos, billboard, atau majalah. Penerima atau wisatawan, jika digiring ke suatu promosi, harus men-dekoding atau menerjemahkan maknanya. Kemudian, wisatawan dapat mengambil tindakan, seperti pergi ke toko atau melakukan pembelian (Durianto, 2003:89). 


\section{Media Online dan Internet}

Istilah internet merupakan singkatan dari Interconnection Networking. Secara sederhana, internet bisa diartikan sebagai a global networkof computer networks (Tjiptono dan Totok, 2001: 2). Menurut Tjiptono (2001: 8) pemanfaaatan internet sebagai media online atau riset memberikan bebarapa keunggulan, diantaranya :

a. Konektivitasdan jangkauan global. Di dunia maya, jaringan yang terjalin adalah jaringan global. Dengan demikian akses data dan informasi melampaui batas batas negara.

b. Akses 24 jam. Akses informasi di internet tidak dibatasi waktu, karena dengan lingkup global, dunia maya yang di hadirkan tidak pernah tidur

c. Kecepatan. Bila dibandingkan dengan sumber dta tradisonal, riset melalui internet jauh lebih cepat, karena bersifat real-time.

d. Kenyamanan. Peneliti lewat internet tidak harus menghadapi berbagai persoalan birokratis seperti ijin dari berbagai instasi untuk keperluan pengumpulan data.

e. Kemudahan akses. Menjamurnya bisnis warung internet di Indonesia membuat akses terhadap internet menjadi lebih nyaman dan mudah memanfaatkan internet untuk keperluan riset maupun tujuan lainnya.

Secara garis besar, kemajuan teknologi internet yang diseertai dengan berkembangnya bermacam - macam titik akses seperti World Wide Web atau www membawa tiga implikasi utama, yaitu (Tjiptono dan Diana, 2000: 20) :

1. percepatan globalisasi industri. Akses ke WWW membuka peluang bagi setiap perusahaan memasuki pasar global. Perkembangan infrastruktur jaringan intra dan interkorporasi memudahkan perusahaan untuk melakukan era ' $c o-R D$ dan co-marketing.

2. Multidimensionalitas proses penciptaan nilai. Pada prinsipnya, WWW dan jaringan sejenis lainnya bukan sekedar infrastruktur, namun sekaligus juga pasar.

3. Tingkat hambatan masuk industri. Infrastruktur informasi berdampak signifikan pada hambatan masuk industri. Di satu sisi, dalam kasus tertentu akses infrastruktur informasi menghadirkan peluang bisnis globalyang bahkan sebelumnya tidak terbayangkan. Namun disisi lain, dalam beberapa industry jasa berbasis informasi yang sudah mapan, infrastruktur informasi yang sifatnya industry-specificjustru menciptakan hambatan masuk yang signifikan.

Dalam traditional market place, lalu lintas informasi produk/jasa, dan pembayaran bersifat fisik. Dengan kata lain, model bisnis yang berlaku adalah geographic business model. Sebaliknya, dalam dunia virtual market space, aliran informasi produk, proses komunikasi antara produsen dan wisatawan, distribusi produk/jasa dan transaksi berlangsung dalam dunia maya atau virtual. Maka dari itu untuk 
mengkases seluruh informasi dalam dunia virtual diperlukan aplikasi guna memudahkan pengguna dalam mengakses internet.

Menurut Tjiptono dan Diana, aplikasi internet untuk keperluan bisnis meliputi delapan bidang pokok, diantaranya:

a. yellow pages, berupa database terorganisasi yng memuat aneka ragam informasi produk, perusahaan, iklan, berita, hiburan dan sebagainya.

b. Web traffic control, berfungsi sebagai iklan yang menarik perhatian para pemakai internet agar mengunjungi situs tertentu.

c. On-line store front, berupa gerai penjualan virtual seperti amazon.com maupun mal - mal lain.

d. Business-to-business links, berupa koneksipada jaringan bisnis yang dimiliki perusahaan.

e. Community sites, seperti ruang ngobrol atau chatting room khusus untuk kelompok pelanggan tertentu.

f. Standart website, berupa homepage dan alamat e-mailuntuk kontak dan layanan pelanggan.

g. Informational atau image sites, yang tidak memiliki fungsi komersial langsung, namun lebih menekankan aspek penyajian informasi.

h. Content-based sites, dimana pemakai harus membayar biaya keanggotaan agar bisa mendapat akses ke isi situs itu.

\section{Minat Pembelian}

Minat pembelian adalah tahapan dimana wisatawan mencari informasi membandingkan dan memikirkan tentang kemungkinan bahwa produk itu mampu memenuhi kebutuhannya.Menurut Schiffman dan Kanuk (2004: 25), pengaruh eksternal, kesadaran akan kebutuhan, pengenalan produk dan evaluasi alternatif adalah hal yang dapat menimbulkan minat beli wisatawan. Pengaruh eksternal ini terdiri dari usaha pemasaran dan faktor sosial budaya.Menurut Simamora (2002: 131) minat adalah sesuatu yang pribadi dan berhubungan dengan sikap, individu yang berminat terhadap suatu obyek akanmempunyai kekuatan atau dorongan untuk melakukan serangkaian tingkah laku untuk mendekati atau mendapatkan objek tersebut.

Menurut Kotler dan Keller (2003:181), customer buying decision - all their experience in learning, choosing, using, even disposing of a product. Yang kurang lebih memiliki arti minat beli wisatawan adalah sebuah perilaku wisatawan dimana wisatawan mempunyai keinginan dalam membeli atau memilih suatu produk,berdasarkan pengalaman memilih, menggunakan mengkonsumsi atau 
menginginkan suatu produk.Faktor - faktor mempengaruhi minat berhubungan dengan perasaan dan emosi, bila seseorang merasa senang dan puas dalam membeli barang atau jasa maka hal itu akan memperkuat minat membeli, ketidakpuasan biasanya menghilangkan minat (Swasta dan Irawan, 2001).

\section{METODE PENELITIAN}

\section{Populasi dan Sampel}

Populasi dalam penelitian ini adalah wisatawan yang memberikan testimoni atau ungkapan terhadap destinasi wisata banyuwangi yang pernah dikunjungi yang berjumlah 700 orang yang terdaftar pada website. Karena jumlah populasi terlalu banyak, sehingga menyulitkan melakukan penelitian. Maka penelitian menggunakan sampel. Ferdinand (2002:5) menyarankan bahwa ukuran sampel tergantung pada jumlah indikator yang digunakan dalam seluruh variabel laten. Jumlah sampel adalah sama dengan jumlah indikator dikalikan 5 sampai dengan 10. Maka jumlah sampel pada penelitian ini adalah $(11 \times 8)=88$.

Subjek dan informan diambil menggunakan metode non-probability sampling, dimana tidak semua orang yang termasuk dalam sampel populasi memiliki peluang yang sama untuk dipilih menjadi anggota sampel. Adapun teknik non-probability sampling yang digunakan yaitu teknik purposive sampling, dimana sampel dipilih berdasar kriteria - kriteria tertentu yang di tentukan dalam penelitian.Adapun kriteria yang ditentukan sebagai responden adalah pelanggan yang memberikan testimoni pada destinasi wisata yang dikunjungi di Banyuwangi selama tahun 2018.

\section{Teknik Pengumpulan Data}

Kuisioner ialah sejumlah pernyataan tertulis yang digunakan untuk memperoleh informasi dan responden, selanjutnya responden diminta untuk mengisi daftar pernyataan tersebut. Kuisioner yang diberikan kepada responden pada penelitian ini adalah menggunakankuisioner online menggunakan google document. Penggunaan google document memungkinkan peneliti untuk menerbitkan dan menyebarkan kuisioner secara luas dan cepat karena terhubung dengan jaringan internet.

\section{Analisis Data}

Penggunaan metode EPIC model bertujuan untuk mengetahui dampak komunikasi iklan tersebut terhadap wisatawan dalam mempengaruhi keputusan pembelian. Penelitian dilakukan untuk mendapatkan nilai empathy, persuasion, impact, dan communication dari iklan online destinasi wisata banyuwangi. Penelitian ini menggunakan skala likert, dengan rentang skala sebagai berikut: 


$$
R s=\frac{R(b o b o t)}{M}
$$

Keterangan :

$\mathrm{R}$ (bobot) = bobot terbesar sampai bobot terkecil

$\mathrm{M} \quad=$ Banyaknya kategori bobot

Sehingga rentang skala likert yang didapat adalah:

$$
R s=\frac{5-1}{5}=0,8
$$

Posisi keputusan yang didapat adalah :

Tabel 1

Rentang Skala Keputusan EPIC Model

\begin{tabular}{ccc}
\hline No & Rentang Skala & Kriteria Keputusan \\
\hline 1 & $1,00<\mathrm{x} \leq 1,80$ & Sangat tidak efektif \\
2 & $1,80<\mathrm{x} \leq 2,60$ & Tidak efektif \\
3 & $2,60<\mathrm{x} \leq 3,40$ & Cukup \\
4 & $3,40<\mathrm{x} \leq 4,20$ & Efektif \\
5 & $4,20<\mathrm{x} \leq 5,00$ & Sangat Efektif \\
\hline Sumber: AC Nielsen, data diolah, September 2018
\end{tabular}

Sehingga diketahui rentang skala keputusan yang dapat dilihat dari gambar dibawah ini:

STE

TE

$\mathrm{C}$

$\mathrm{E}$

SE

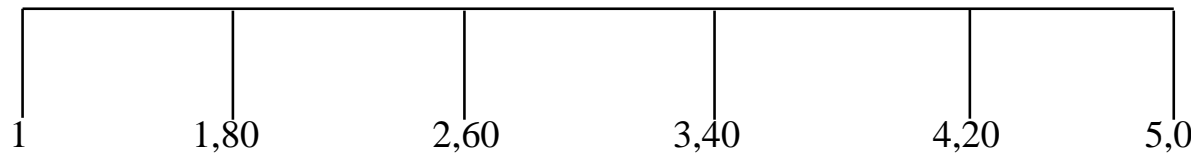

Gambar 1

Rentang Skala Keputusan

\section{Analisis Tabulasi Sederhana}

Hasil dari analisis tabulasi sederhana, variabel empathy dapat terlihat pada tabel dibawah ini: 
Tabel 2

Faktor Empathy Responden Terhadap Iklan Online Destinasi Wisata Banyuwangi

\begin{tabular}{lccc}
\hline \multicolumn{1}{c}{ Atribut } & \multirow{2}{*}{ Bobot } & \multicolumn{2}{c}{ Jumlah responden } \\
& & Emphaty-1 & Empathy-2 \\
\hline Sangat tidak setuju & 1 & 1 & 1 \\
Tidak setuju & 2 & 8 & 10 \\
Cukup & 3 & 29 & 24 \\
Setuju & 4 & 35 & 45 \\
Sangat setuju & 5 & 15 & 8 \\
\hline
\end{tabular}

Sumber: data diolah, September 2018

Dari hasil analisis tabulasi sederhana diatas, jawaban responden yang paling dominan terhadap dua pernyataan variabel empathy adalah "setuju" dengan bobot empat poin. Hasil dari analisis tabulasi sederhana, variabel empathy dapat terlihat pada tabel dibawah ini:

Tabel 3

Faktor Persuasion Responden Terhadap Iklan OnlineDestinasi Wisata Banyuwangi

\begin{tabular}{lccc}
\hline \multirow{2}{*}{ Atribut } & Bobot & \multicolumn{2}{c}{ Jumlah responden } \\
& & Persuasion-1 & Persuasion-2 \\
\hline Sangat tidak setuju & 1 & 1 & 1 \\
Tidak setuju & 2 & 7 & 13 \\
Cukup & 3 & 17 & 23 \\
\hline Setuju & 4 & 47 & 41 \\
Sangat setuju & 5 & 16 & 10 \\
\hline Sumber: data diolah, September 2018 & &
\end{tabular}

Hasil analisis tabulasi sederhan diatas, dapat disimpulkan bahwa jawaba responden terhadap dua pernyataan variabel peruasion adalah setuju dengan bobot empat poin. Hasil dari analisis tabulasi sederhana, variabel empathy dapat terlihat pada Tabel 4 dibawah ini.

Hasil analisis tabulasi sederhan diatas, dapat disimpulkan bahwa jawaba responden terhadap dua pernyataan variabel peruasion adalah setuju dengan bobot empat poin.

Hasil dari analisis tabulasi sederhana, variabel empathy dapat terlihat pada tabel dibawah ini: 
Tabel 4

Faktor Impact Responden Terhadap Iklan OnlineDestinasi Wisata Banyuwangi

\begin{tabular}{lccc}
\hline \multicolumn{1}{c}{ Atribut } & Bobot & Impact -1 & $\begin{array}{c}\text { Jumlah responden } \\
\text { Impact- } 2\end{array}$ \\
\hline Sangat tidak setuju & 1 & 0 & 0 \\
Tidak setuju & 2 & 2 & 15 \\
Cukup & 3 & 19 & 32 \\
Setuju & 4 & 47 & 33 \\
Sangat setuju & 5 & 20 & 8 \\
\hline
\end{tabular}

Sumber: data diolah, September 2018

Hasil analisis tabulasi sederhan diatas, dapat disimpulkan bahwa jawaban responden terhadap dua pernyataan variabel impact adalah setuju dengan bobot empatpoin. Hasil dari analisis tabulasi sederhana, variabel empathy dapat terlihat pada tabel dibawah ini:

Tabel 5

Faktor Communication Responden Terhadap Iklan OnlineDestinasi Wisata Banyuwangi

\begin{tabular}{lccc}
\hline \multicolumn{1}{c}{ Atribut } & & \multicolumn{2}{c}{ Jumlah responden } \\
Sangat tidak setuju & 1 & 2 & Communication-2 \\
Tidak setuju & 2 & 4 & 1 \\
Cukup & 3 & 21 & 3 \\
Setuju & 4 & 40 & 32 \\
Sangat setuju & 5 & 21 & 32 \\
\hline
\end{tabular}

Sumber: data diolah, September 2018

Hasil analisis tabulasi sederhan diatas, dapat disimpulkan bahwa jawaba responden terhadap dua pernyataan variabel communication adalah setuju dengan bobot empat poin.

a. Skor Rata - Rata

1. Variabel Empathy

Dari tabel 4.7 diperoleh nilai variabel empathy, sebagai berikut:

$\bar{X}(E 1)=\frac{(1 \times 1)+(2 \times 8)+(2 \times 29)+[4 \times 15)+(5 \times 15)}{89}=3,7$ 


$$
\begin{aligned}
\bar{X}(E 2)=\frac{(1 \times 1)+(2 \times 10)+(9 \times 24)+(4 \times 45))+(5 \times 8)}{8 g}=3,6 \\
\bar{X} \text { Empathy }=\frac{3,7+3,6}{2}=3,65
\end{aligned}
$$

$$
\text { STE }
$$

TE

$\mathrm{C}$

$\mathrm{E}$

SE

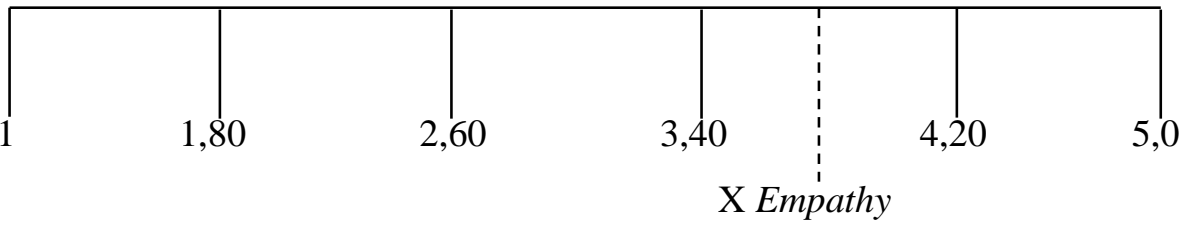

Gambar 2

Nilai Variabel Empathy

Sumber: data diolah, September 2018

Hasil dari analisis penelitian pengukuran efektifitas iklan online destinasi wisata banyuwangi pada laman atau website berdasarkan EPIC model diketahui dimensi empathy iklan online destinasi wisata banyuwangi masuk dalam rentang skala efektif. Hal ini mengindikasikan bahwa pelanggan menyukai iklan onlinedestinasi wisata banyuwangi, sehingga iklan tersebut dapat memberikan informasi yang berharga tentang daya tarik destinasi wisata banyuwangi bagi wisatawan.

\section{Variabel Persuasion}

Dari tabel 4.8 diperoleh nilai atau skor rata-rata variabel persuasion, sebagai berikut:

$$
\begin{aligned}
& \bar{X} P 1=\frac{(1 \times 1)+(2 \times 7)+(3 \times 17)+(4 \times 47)+(5 \times 16)}{88}=3,8 \\
& \bar{X} P 2=\frac{(1 \times 1)+(2 \times 13)+(3 \times 23)+(4 \times 41)+(5 \times 10)}{88}=3,5 \\
& \bar{X} \text { Persuasion }=\frac{3,8+3,5}{2}=3,65
\end{aligned}
$$

$\mathrm{C}$

$\mathrm{E}$

SE

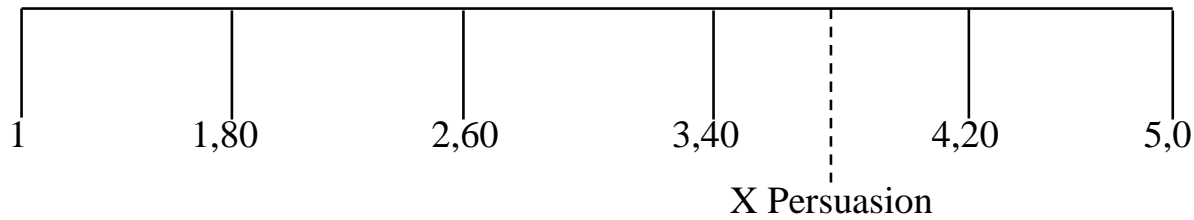

Gambar 3

Nilai Variabel Persuasion 
Hasil dari analisis penelitian pengukuran efektifitas iklan online destinasi wisata banyuwangi pada laman atau website berdasrkan EPIC model diketahui dimensi persuasion iklan onlinedestinasi wisata banyuwangi masuk dalam rentang skala efektif. Hal ini mengindikasikan bahwa iklan destinasi wisata banyuwangi memberikan peningkatan atau penguatan karakter destinasi, sehingga iklan tersebut dapat memberikan dampak terhadap keinginan wisatawan untuk berkunjung kembali pada destinasi wisata.

3. Variabel Impact

Dari tabel 4.10 diperoleh nilai atau skor rata-rata variabel impact, sebagai berikut:

$$
\begin{aligned}
& \bar{X} I 1=\frac{(1 \times 0)+(2 \times 2)+(3 \times 19)+(4 \times 47)+(5 \times 20)}{88}=3,9 \\
& \bar{X} I 2=\frac{(1 \times 0)+(2 \times 15)+(3 \times 32)+(4 \times 33)+(5 \times 8)}{88}=3,4 \\
& \bar{X} \text { Impact }=\frac{3,9+3,4}{2}=3,65
\end{aligned}
$$

STE

TE

$\mathrm{C}$

$\mathrm{E}$

SE

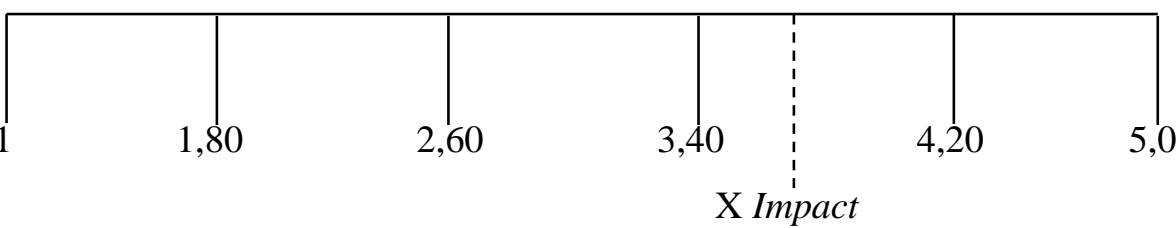

Gambar 4

Nilai Variabel Impact

Sumber: data diolah, September 2018

Hasil analisis penelitian pengukuran efektifitas iklan onlinedestinasi wisata banyuwangi pada media laman atau website berdasarkan EPIC model diketahui dimensi impactdestinasi wisata banyuwangi berada di rentang skala efektif, ini mengindikasikan informasi mengenai produk yang dipasang di laman dapat dipercaya wisatawan dan review destinasi wisata banyuwangi menonjol dibanding destinasi wisata lain yang sejenis.

\section{Variabel Communication}

Dari tabel 4.10 diperoleh nilai atau skor rata-rata variabel communication sebagai berikut:

$$
\begin{aligned}
& \bar{X} C 1= \frac{(1 \times 2)+(2 \times 4)+(3 \times 21)+(4 \times 40)+(5 \times 21)}{88}=3,8 \\
& \bar{X} C 2=\frac{(1 \times 1)+(2 \times 3)+(3 \times 32)+(4 \times 32)+(5 \times 20)}{88}=3,7
\end{aligned}
$$




$$
\begin{aligned}
& \bar{X} \text { Communication }=\frac{3,8+3,7}{2}=3,75 \\
& \text { STE TE } \\
& \text { C } \\
& \text { E } \\
& \text { SE } \\
& \begin{array}{|l|l|l|l|l|l|}
\hline & & & & \\
& & & & \\
& 2,60 & 3,40 & 4,20 & 5,0 \\
& & & \\
\multicolumn{3}{c|}{\text { Communication }}
\end{array}
\end{aligned}
$$

Gambar 5

Nilai Variabel Communication

Sumber: data diolah, September 2018

Hasil analisis penelitian pengukuran efektifitas iklan onlinedestinasi wisata banyuwangi pada laman atau website berdasarkan EPIC model diketahui dimensi communication iklan online destinasi wisata banyuwangi berada di rentang skal efektif. Hal ini menginformasikan bahwa wisatawan dapat mengingat pesan yang disampaikan. Pesan tersebut memberikan kesan yang kuat dan pemahaman akan destinasi wisata banyuwangi.

\section{b. EPIC Rate}

Langkah berikutnya adalah mencari nilai rata-rata EPIC rate. Secara keseluruhan tabel skor dari keempat dimensi dapat dilihat pada tabel 4.11 dibawah ini:

\section{Tabel 6}

Skor EPIC

\begin{tabular}{cccc}
\hline No & EPIC Model & Skor & Keterangan \\
\hline 1 & Empathy & 3,65 & Efektif \\
2 & Persuasion & 3,65 & Efektif \\
3 & Impact & 3,65 & Efektif \\
4 & Communication & 3,75 & Efektif \\
\hline
\end{tabular}

Sumber: data primer diolah, September 2015

Skala penilaian :

$$
\begin{array}{ll}
1,00<\mathrm{x} \leq 1,80 & =\text { Sangat tidak Efektif } \\
1,80<\mathrm{x} \leq 2,60 & =\text { Efektif } \\
2,60<\mathrm{x} \leq 3,40 & =\text { Cukup } \\
3,40<\mathrm{x} \leq 4,20 & =\text { Efektif } \\
4,20<\mathrm{x} \leq 5,00 & =\text { Sangat efektif }
\end{array}
$$




$$
\begin{aligned}
& \text { EPIC Rate }=\frac{\text { Empathy }+ \text { Persuasion }+ \text { Impact }+ \text { communicaton }}{4} \\
& =\frac{3,65+3,65+3,65+3,7}{4}=3,66
\end{aligned}
$$

Hasil akhir EPIC rate adalah 3,66 yang jika dimasukkan kedalam skala penilaian termasuk dalam kategori efektif. Hal ini menunjukkan bahwa iklan onlinedestinasi wisata banyuwangi efektif. Keseluruhan grafik hasil analisis efektifitas iklan onlinedestinasi wisata banyuwangi destinasi wisata banyuwangi dengan metode EPIC model tersaji pada Gambar 6 :

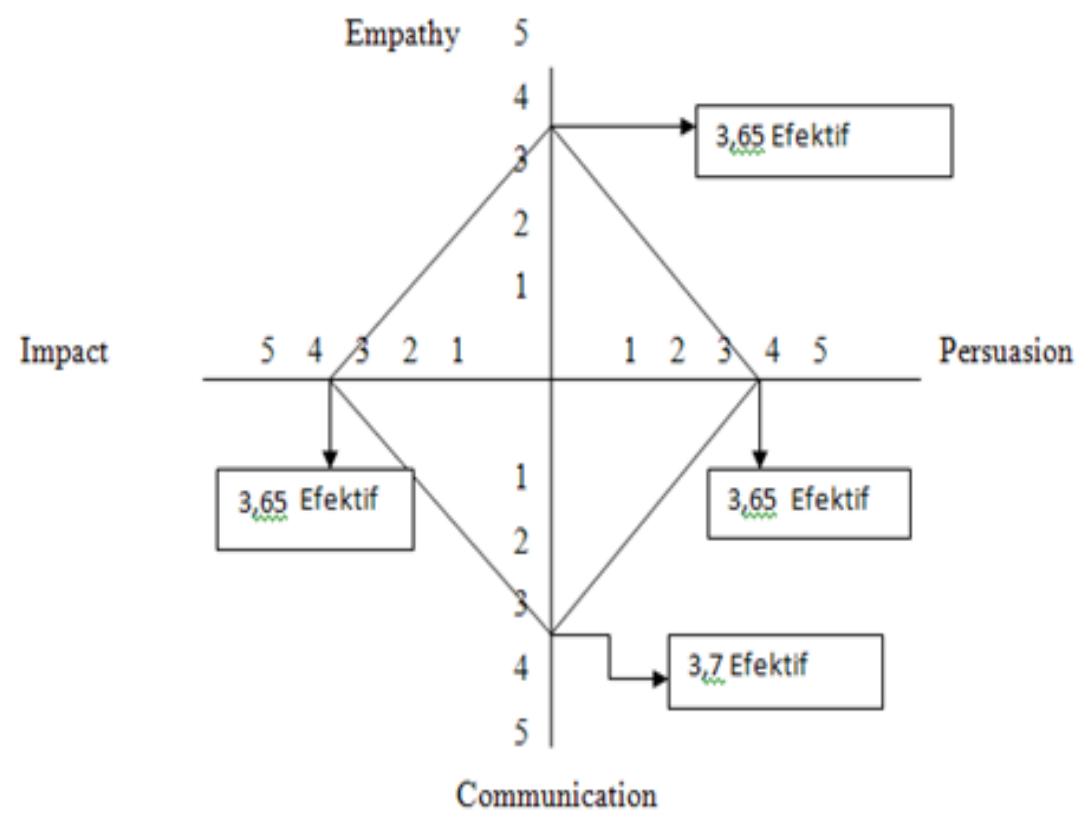

Gambar 6

EPIC Model Iklan OnlineDestinasi wisata Banyuwangi

Sumber: Data primer Diolah, September 2018

\section{PEMBAHASAN HASIL PENELITIAN}

\section{Efektifitas Iklan Online Destinasi Wisata Banyuwangi}

Untuk mengetahui nilai dari EPIC model terlebih dahulu dilakukan analisis tabulasi sederhana serta skor rata - rata dari masing-masing dimensi setelah itu diperoleh 
hasil analisis EPIC dengan monggunakan perhitungan EPIC Rate. Analisis menggunakan EPIC model dilakukan untuk mendapatkan nilai variabelempathy, variabelpersuation, variabelimpact, dan variabelcommunicationdari iklan onlineDestinasi wisata Banyuwangi.

Empathy menginformasikan apakah wisatawan menyukai promosi, dan bagaimana wisatawan melihat hubungan promosi tersebut dengan pribadi mereka, Durianto(2003: 53). Sesuai dengan teori empathypeneliti ingin mengetahui apakah iklan online destinasi wisata Banyuwangi mampu memberikan reaksi yang positif terhadap wisatawan serta mengetahui apakah wisatawan menyukai iklan onlineDestinasi wisata Banyuwangi dan menggambarkan bagaimana wisatawan melihat hubungan antara iklan tersebut dengan pribadi mereka.

Hasil dari analisis yang telah dilakukan, pengukuran efektifitas variabel empathy pada iklan online destinasi wisata Banyuwangi menunjukkan bahwa iklan tersebut termasuk dalam rentang skala efektif dengan rata-rata berbobot 3,65 yang tersaji pada Gambar 4.2 yang berarti iklan onlinedestinasi wisata Banyuwangi yang menginformasikan bahwa wisatawan menyukai iklan onlineDestinasi wisata Banyuwangi, sehingga membuat responden merasakan reaksi positif terhadap pesan iklan, serta mampu menciptakan hubungan antar wisatawan dengan destinasi wisata melalui isi iklan yang mudah dimengerti, sehingga iklan tersebut dapat memberikan informasi yang berharga tentang daya tarik destinasi wisata Banyuwangi. Hasil penelitian ini sejalan dengan penelitian (Ayu et al., 2017; Bestriandita \& Widodo, 2017; Hastuti, 2013; Rahayu, 2012; Riyantoro \& Harmoni, 2013; Salim \& Bachri, 2014).

Dimensi persuasion menginformasikan apa yang dapat diberikan oleh Destinasi wisata Banyuwangi meningkatkan atau penguatan karakter suatu merek, sehingga pemasar dapat memperoleh pemahaman mengenai dampak promosi terhadap keinginan wisatawan untuk mengunjungi suatu destinasi yang ditawarkan. Hasil dari analisis yang telah dilakukan sebelumnya pengukuran efektifitas variabel persuasionpada iklan online Destinasi wisata Banyuwangi menunjukkan bahwa iklan tersebut termasuk dalam kategori efektif dengan rata-rata berbobot 3,65. Hal ini mengindikasikan bahwa iklan online destinasi wisata Banyuwangi dapat meningkatkan dan menguatkan karakter Destinasi wisata Banyuwangi dalam benak wisatawan serta iklan online Destinasi wisata Banyuwangi memiliki dampak terhadap keinginan wisatawanmengunjungDestinasi wisata Banyuwangi kembali. Hasil penelitian ini sejalan dengan penelitian (Ayu et al., 2017; Bestriandita \& Widodo, 2017; Hastuti, 2013; Rahayu, 2012; Riyantoro \& Harmoni, 2013; Salim \& Bachri, 2014).

Variabel impact dalam penelitian ini menunjukkan apakah produk Destinasi wisata Banyuwangi dapat terlihat lebih menonjol dari pada produk lain sejenis dan apakah suatu promosi dapat mengikutsertakan wisatawan dalam pesan yang disampaikan. 
Hasil dari analisis yang telah dilakukan sebelumnyapengukuran efektifitas variabel pada iklan online Destinasi wisata Banyuwangi yang dilakukan pada website menunjukkan bahwa iklan tersebut termasuk dalam kategori efektif dengan bobot rata-rata sebesar 3,65. Hal ini membuktikan bahwa destinasi wisata Banyuwangi telah berhasil dalam memanfaatkan media online sebagai periklanan yang menunjang kegiatan pemasaran serta hal ini mengindikasikan bahwa iklan destinasi wisata Banyuwangi mampu menonjolkan produk destinasi wisatanya daripada destinasi wisata daerah lainnya yang sejenis.Hasil tersebut sesuai dengan penelitian terdahulu yang dilakukan oleh Jimmy Satria dimana pada penelitian tersebut variabel impactmemperoleh hasil sebesar 3,886. Nilai tersebut bcrada pada rentang skala dimana variabel impact suatu iklan dinyatakan efektif.Hasil penelitian ini sejalan dengan penelitian (Ayu et al., 2017; Bestriandita \& Widodo, 2017; Hastuti, 2013; Rahayu, 2012; Riyantoro \& Harmoni, 2013; Salim \& Bachri, 2014).

Variabel communicationatau dimensi komunikasi memberikan informasi mengenai kemampuan wisatawanDestinasi wisata Banyuwangi dalam mengingat pesan utama yang disampaikan, pemahaman wisatawanDestinasi wisata Banyuwangi , kekuatan kesan yang ditinggalkan serta kejelasan promosi yang dilakukan Destinasi wisata Banyuwangi melalui iklan online. Hasil dari analisis yang telah dilakukan sebelumnya pengukuran efektivitas variabel communication di Destinasi wisata Banyuwangi yang menginformasikan bahwa iklan tersebut termasuk pada kategori efektif dengan skor rata-rata 3,75 yang menginformasikan bahwa wisatawan dapat mengingat pesan utama yang disampaikan dalam iklan serta iklan online yang dibuat destinasi wisata Banyuwangi meninggalkan kesan yang kuat dan pemahaman wisatawan akan produk dari destinasi wisata Banyuwangi .Hasil penelitian ini sejalan dengan penelitian (Ayu et al., 2017; Bestriandita \& Widodo, 2017; Hastuti, 2013; Rahayu, 2012; Riyantoro \& Harmoni, 2013; Salim \& Bachri, 2014).

Setelah mengetahui nilai masing - masing dimensi EPIC model hal selanjutnya yang dilakukan adalah mencari nilai rata - rata EPIC rate menjumlahkan keempat nilai dimensi kemudian dibagi empat. Berdasarkan perhitungan yang telah dilakukan pada hasil analisis EPIC rate diperoleh nilai EPIC rate sebesar 3,66 yang jika dimasukkan kedalam skala penilaian termasuk dalam kategori efektif yang memberikan arti bahwa iklan online destinasi wisata Banyuwangi efektif. 


\section{KESIMPULAN DAN SARAN}

\section{Kesimpulan}

Pendekatan EPIC rate pada penelitian ini menghasilkan kesimpulan bahwa keempat dimensi yang digunakan bernilai positif atau efektif. Artinya iklan online destinasi wisata Banyuwangi berjalan efektif baik dari sisi empati, persuasi, dampak dan aspek komunikasi. Konsep sustainibility dalam membangun pariwisata harus tetap dilakukan sehingga destinasi wisata Banyuwangi diharapkan mampu untuk mempertahankan dan meningkatkan kinerja promosi produk pariwisata sehingga diperoleh hasil maksimal.

\section{DAFTAR PUSTAKA}

Ayu, K., Indrawati, P., Sudiarta, I. N., \& Suardana, I. W. (2017). Efektivitas Iklan Melalui Media Sosial Facebook Dan Instagram Sebagai Salah Satu Strategi Pemasaran Di Krisna Oleh-Oleh Khas Bali, 17(2), 78-83.

Bestriandita, D., \& Widodo, E. (2017). Analisis Perbandingan Efektivitas Iklan Menggunakan EPIC Model Terhadap Mahasiswa UII Yogyakarta. In Prosiding Si MaNIs (Vol. 1, pp. 214-220).

BPS Kabupaten Banyuwangi. (2018). Kabupaten Banyuwangi dalam Angka 2018. Banyuwangi: BPS Kabupaten Banyuwangi.

Durianto, Darmadi. 2003. Invasi Pasar Dengan Iklan Yang Efektf. Jakarta:Erlangga

Ferdinand, A. 2002. SEM dalam Penelitian Manajemen Edisi 2. Semarang: Badan Penerbit Universitas Semarang.

Hastuti, S. (2013). Efektivitas iklan layanan masyarakat di televisi. Jurnal Ilmu Komunikasi, 2(2), 67-72.

Kottler, P. dan Keller, K. L. 2009. Manajemen Pemasaran Edisi Ketiga Belas. Jakarta: Erlangga.

Nugroho, Agung.2005. Strategi Jitu Memilih Metode Statistik Penelitian dengan SPSS. Yogyakarta: Andi Yogyakarta.

Rahayu, D. D. (2012). Pengaruh iklan dengan epic model pada media televisi terhadap sikap penonton. Jurnal Sosial Ekonomi Pembangunan, (6), 290320.

Riyantoro, B., \& Harmoni, A. (2013). Efektivitas Iklan Melalui Jejaring Sosial Sebagai. In Proceeding PESAT (Vol. 5, pp. 8-9). Bandung.

Salim, M., \& Bachri, S. (2014). Pengaruh C elebrity Endorser terhadap Keputusan Pembelian Produk di Indonesia ( Penelitian Online ), 12, 230-238.

Schiffman dan Kanuk. 2004. Periklanan Wisatawan. Jakarta: Prentice Hall. 
Simmamora, Bilson. 2002. Panduan Riset Periklanan Wisatawan. Jakarta: Gramedia Pustaka Utama.

Swastha, Basu dan Irawan. 2001. Manajemen Pemasaran Modern. Yogyakarta: Liberty Tjiptono, Fandy dan Anastasia Diana. 2000. Prinsip dan Dinamika Pemasaran. Yogyakarta: JJ. Learning

Umar, H. 2003. Metode Riset Periklanan Wisatawan Jasa. Jakarata: Ghalia Indonesia

Wijaya, N., \& Dharmayanti, D. (2014). Analisa Efektivitas Iklan Kosmetik Wardah Dengan Menggunakan Consumer Decision Model ( Cdm ). Jurnal Manajemen Pemasaran, 2(1). 